\title{
Seeking the Elusive Fit: What do Educational Leaders Look for When Hiring New Teachers for First Nations Schools?
}

\author{
Jerome Cranston \\ University of Manitoba
}

\begin{abstract}
This article reports on the preliminary findings of a qualitative research study that explored the perceptions of five directors of education in Manitoba's First Nations' educational authorities as they assess prospective teachers for fit for both their schools and their local communities. The findings of this study illustrate that in order to meet the challenges of teaching effectively in First Nations' schools, those responsible for hiring teachers want to find candidates who (a) contribute to the establishment of a new culture of teaching in the schools, (b) form respectful relationships with students and other members of the particular First Nation community, (c) possess a worldview that is commensurate with those held by First Nations peoples, and (d) are competent to teach academic subjects and also support students' development as Indigenous youth. I conclude with recommendations that can support the preparation of a greater number of prospective teachers capable of teaching effectively in First Nation schools.
\end{abstract}

Keywords: First Nations education; Teacher recruitment and selection; educational leadership 


\section{Seeking the Elusive Fit: What do Educational Leaders Look for When Hiring New teachers for First Nations Schools?}

The achievement gap between Aboriginal and non-Aboriginal students is most profound between those who attend band-controlled, on-reserve schools and those who do not attend on-reserve schools. First Nations students who attend on-reserve schools face persistent barriers that hinder their opportunities for learning. These barriers far exceed any facing non-Aboriginal Canadian students. Among them is the reality that many First Nation communities struggle to find teachers who are both adequately prepared and culturally competent to meet the educational needs of First Nation students (Canadian Council on Learning, 2008; Domangue \& Carson, 2008; National Panel on First Nations Elementary and Secondary Education for Students on Reserve, 2012; Parliament of Canada, 2011).

However, trying to attract and retain teachers, whether they identify as Aboriginal or non-Aboriginal, who not only understand First Nations history, culture, intellectual traditions, and languages but also comprehend First Nations' relationships with the land is a formidable task (Anderson, Horton, \& Orwick, 2004). One of the most significant challenges of attracting and retaining qualified teachers is the limited funding these schools receive from the federal government, which limits their ability to offer compensation-wages, benefits, and pensions-at levels that are competitive with neighbouring public school districts. Due to these financial pressures and the geographic isolation of some First Nations reserves, many schools experience high staff turnover rates (Kavanagh, 2000, 2006; Wotherspoon, 2009).

In order to address the issues associated with recruiting and retaining a teacher workforce that is prepared for and committed to meeting the unique learning needs of First Nation students, it is important to gain some insight into the what the individuals responsible for hiring teachers for on-reserve schools think are important attributes in prospective teachers (Anderson et al., 2004; Bell et al., 2004).

\section{The Significance of Understanding School Culture}

Stoll (2002) proposed that, "school culture is one of the most complex and important concepts in education" (p. 9). Culture not only shapes reality for the adults who work within a school, but also it supports the development of a sense of collective professional identity for staff and creates a framework for understanding organizational life (Stoll). As Deal and Peterson (1999) observed:

School cultures are complex webs of traditions and rituals that have built up over time as teachers, parents and administrators work together and deal with crises and accomplishments....Cultural patterns are highly enduring, have a powerful impact on performance, and shape the ways people, think, act, and feel. (p. 4)

Moreover, Sergiovanni (1995) maintained that school culture governs what is of worth for those within the school and influences how people think, feel, and behave. The establishment of nurturing and supportive school climate and culture is equally as important a factor, if not more so, in supporting the success of First Nations students who attend on-reserve schools (Bell et al., 2004; Fulford, 2007). 
As alike as many schools may be, there remains a unique culture within each school (Goodlad, 1984; Patterson, Purkey, \& Parker, 1986; Wagner 2006). This culture provides a focus and clear purpose for the school and becomes the cohesive force that bonds the school community together as it goes about its mission (Deal \& Peterson, 1999). However, it may also work against improvement and reform efforts (Barth, 2006; Peterson, 2002). Whether a school's culture ultimately helps to support student learning or not, research demonstrates that in the hiring process prospective teachers are assessed against perceptions of fitting into this culture or not (Cranston, 2012a).

The notion that employers seek to hire applicants based on their fit-to-job and organizational characteristics has long been recognized in the management literature (Tom, 1971). Yet the term fit is an elusive construct. It is most commonly assessed during the employment interview and assessments of fit extend considerably beyond the technical job requirements of teaching (Cranston, 2012a). While, perhaps, an elusive construct, Bell et al. (2004) and Fulford (2007) concluded that educational leaders in successful Aboriginal schools work hard to find capable and effective teachers who can fit into and support the school and, community, and, most importantly, can enable students to succeed at school.

\section{Conceptual Orientation}

The conceptual orientation of this study was developed from a general understanding of person-organization (P-O) fit, which is broadly defined as the compatibility between individuals and organizations (Kristof-Brown, 1996). For hiring purposes, the P-O fit concept dictates a necessity to select persons whose attitudes, behaviours, and values are consistent with the defining features of the employer's organizational culture (KristofBrown, 1996). In the case of schools, employers not only search for teachers with appropriate credentials but also look for specific behaviours and attitudes that confirm, or disaffirm, their belief in the fit between a candidate and the organization (Cranston, 2012a; Kristof-Brown, 1996). Some elements of the assessment of fit become more important after applicants have been deemed adequately qualified to perform the work and are often the determinative factors in decisions when hiring authorities extend job offers (Cranston, 2012b). When applied to First Nations schools, an absence of fit could mean that applicants are technically qualified for teaching but that they may not be suited for teaching and living in the culture of First Nation communities and/or schools that are permeated by First Nations' worldviews.

Highlighting the critical roles teachers play in the academic success of First Nation students, Anderson et al. (2004) stated:

A relevant First Nations education system has the mandate and personnel to provide the curriculum, resources and professional development opportunities for all teachers of First Nations on-reserve students. This system will maintain and support current teachers and educate and recruit new teachers that are committed to Indigenous communities. (p. 2)

Preparing teachers who can understand the lived experiences of the families and children they teach in First Nation communities is vital (Anderson et al., 2004; Bell et al., 2004). 
Given the importance of teachers to the success of First Nations students and the pressures to attract and retain them, it is imperative to examine what those responsible for selecting teachers for First Nation schools are looking for when hiring teachers. For the purpose of this study, culture was regarded as a holistic way of being and is a worldview composed of the composite beliefs that stimulate the thinking, guide the actions, and inspire the creativity of a people (Hill, 1995, p. 4). In this regard, culture can be understood as that which characterizes one society and separates it from another or as Geisler (2000) noted:

Culture marks the corners and edges of place; it selects which places will be sacred and which will be sacrificed; it yields maps of place and bestows place names; it defines tenure and imbues ownership types with social distinction; and it decides the aesthetics and ethics of the land. (p. 52)

Thus, this study was designed with a deliberative attentiveness to avoid perpetuating the historical discrimination of Indigenous peoples through the application of a form of cultural essentialism that classifies First Nations' cultures through a Eurocentric view of the world and limits understandings of what constitutes culture to a concept imposed by a dominant group (St. Denis, 2009). Understanding the processes of how individuals are selected for teaching positions in First Nations schools using this multitudinous view of culture is a matter of import not only to those involved in hiring decisions but also to those concerned with the success of First Nations students.

\section{A Research Approach Accountable to Indigenous Standards}

In the original plan of the study, the research method was designed to use individual semi-structured interviews, as part of a naturalistic qualitative methodology, which would yield data that to be coded and analyzed (Creswell, 2012). Using a convenience sampling approach (Creswell, 2012), five directors of education of a First Nation educational authority in Manitoba were contacted via email and invited to participate in the study. I conducted interviews with each director. Four of the five interviews were conducted in the First Nation community where the directors worked and the fifth interview occurred at a location outside of the community at the participant's request.

Very early on during the data collection stage it became apparent to me that my strategy to use prescribed and scripted interview questions was not necessarily the most appropriate approach to conduct interviews in this research context. Accordingly, while unplanned, I adjusted the structure of the interview to allow a more natural conversation to occur. This adjustment is consistent with the recommendations of Davidson-Hunt and O'Flaherty (2007) and Wilson (2008) who suggested that the power associated with the traditional relationships between researchers and Indigenous peoples may require researchers to develop alternative research approaches that address the limitations of conventional research methods. It was clear in the first meeting and each subsequent one that the research participants not only wanted to offer personal accounts of the challenges and opportunities they faced in hiring teachers but also to provide some insight into their own lives and how their lived experiences impacted their roles as educational leaders in First Nations’ communities. 
The research interviews became much more conversational exchanges between the researcher and the participants where the researcher contentedly relinquished a position of privilege over the participants and instead allowed the conversations to evolve more naturally (St. Denis, Battiste, \& Bouvier, 1999; Shapes, 2011). Many of the questions were developed impromptu as I attempted to understand the complex world of the lived experiences of First Nations' educational leaders from the point of view of those who lived them (Schwandt, 2000; Shapes, 2011).

This modification was consistent with the recommendations of scholars of Indigenous research approaches such as Kovach (2009) and Wilson (2008) who underscore that people are motivated by their sense of fulfillment of their basic needs as they live out relationships and those relationships form reality. As the participants shared information through the telling of their stories, I tried to be a sensitive and attentive listener asking questions as necessary (Elbaz-Luwisch, 2007; Polkinghorne, 1995).

Prior to analyzing the narratives, the transcripts of the conversations were returned to each participant to be screened not only for accuracy in transcription but also to ensure that the words reflected the intended meanings of the participants (Creswell, 2012). Upon the return of the transcripts, the analytic approach used to make meaning of the stories was drawn from paradigmatic reasoning, which Bailey and Jackson (2003) suggested is a logical way of knowing important facts, using a classification system to bring order to various elements in the five stories offered by the participants. Each transcript was scrutinized, read and re-read as a story to best understand the internal logic of it, and then read a third time to explore common themes that appeared across the five individual stories (Bailey \& Jackson, 2003; Webster \& Mertova, 2007).

\section{The Participants and Their Communities}

All of the participants were members of a First Nation community located in Manitoba. Two of the directors worked in a First Nation community other than the one to which they belonged, while the other three worked in their home communities. The administrative experience of the participants varied from a minimum of three years of experience as a director of education to a maximum of 11 years of experience. In addition, the participants' educational backgrounds varied with four having completed a graduate degree in educational administration, specifically having earned a Master of Education, and one having completed a Bachelor of Education degree.

Three of these First Nation communities were relatively close to an urban center, in particular less than 300 kilometers from Winnipeg, which is Manitoba's provincial capital and largest city, while the other two were more remote being located at least 800 kilometers away from Winnipeg. In addition, the communities varied in population with the smallest one reported as having 300 residents and the largest reported as having 3000 people who called it home (Government of Canada, 2011).

In order to respect the confidentiality of the participants, the names of the five directors and any information that might identify their home communities has been replaced with pseudonyms that match one of five mountains located in Nepal, specifically, they are Kangchenjunga, Lhotse, Makalu, Cho Oyu, and Dhaulagiri. These five mountains are considered sacred by many of Nepal's Indigenous peoples. The choice 
to use the names of these sacred Indigenous spaces as pseudonyms for the participants is done neither glibly nor out of disrespect to the participants and their communities. In making this choice, I reached back into my own Indigenous cultural heritage to use the names of five sacred places to represent respectfully these directors of education of First Nations educational authorities.

\section{Findings}

The preliminary findings revealed that these directors of education consider four particular criteria to be significant in the screening process and final selection of candidates who they think will be not only effective as teachers but also fit effectively into their specific First Nation schools and communities. In general terms, they want teachers who (a) can help establish a new culture of teaching in the schools, (b) can establish appropriate relationships with students and other members of the First Nation community, (c) possess a worldview that is commensurate with those held by First Nations peoples, and (d) are both competent to teach academic content subjects and to support students understanding Indigenous culture, history, and worldviews.

\section{Wanting to Change the Culture of Teaching}

It was clear that the hiring decisions being considered by these directors were seen as having a lasting impact on the organizational culture of the school. Specifically, these directors commented on searching for prospective teachers who could help change the existing culture of the schools' staffs. This was perhaps best illustrated by the comments made by Kangchenjunga who stated:

[In the past] they [teachers] were allowed to do anything they wanted to do. And, that is why a lot of non-First Nation teachers wanted to come up here to the reserves to teach; because they were allowed to do anything they wanted to do in the classroom. When I became director I evaluated the existing staff I had and found that many teachers were not teaching Science. I found that the majority of teachers in the junior high and elementary schools were only teaching the most basic mathematics concepts. I still find teachers are teaching the English curriculum in broken up components rather than the way teachers are asked to teach in the rest of the province. Things needed to change. I started to ask teachers for their lesson, unit, and yearly plans...some teachers decided to retire, while others resigned. I had one teacher complain to me that she couldn't believe that it was one of her own people who was doing this to her and that she never had to do this before. I guess by "her own people” she meant me. But, to me, I needed to change their attitudes about teaching. When I hire teachers I want ones who will change how we do things around here. (personal communication, November 2012)

Or, as was pointed out by Cho Oyu:

We have identified a challenge, [which is] that we need to help [our current] teachers upgrade their planning and assessment skills. That is a major professional development thrust right now. I know there is a lot of resistance from our teachers, some of who have been with us for many years. They are resistant to 
make changes we need to make. Our younger teachers though seem to be more willing to learn new things. It's how we are changing. (personal communication, October 2011)

It was also clear that some of the teachers currently on the schools' staffs were not interested in being asked to change practices and conceptions of what it meant to be an effective teacher for on-reserve students. As was noted:

When I first got here [as director of education] one teacher walked into my office because I was ready to make some changes in how we did things. She told me the previous director would do this or that. She said she knew how to teach and what our people needed. She went on and on about how the previous director did things. I told her I was not the previous director and that he was working over there [pointing]. Then I asked her if she wanted to go over there and work with him? I've been hiring people who will work with me. (Lhotse, personal communication, October 2011)

These examples illustrate that one of the critical attributes that these directors of education are looking for in new teachers is their ability to help realign and re-culture the school staff's professional expectations and norms that they perceived as needed for better support of First Nations students' success (Hargreaves, 1997). These five directors believed, as research demonstrates (Cranston, 2012a, 2012b; Peterson, 2002; Peterson \& Deal, 2002), that their hiring decisions could impact a school's culture. The finding aligns with other research that has demonstrated that a positive climate and healthy culture in a First Nations school can create and maintain a constructive learning environment that positively influences school-wide student achievement (Bell et al., 2004; Fulford, 2007).

\section{It is All About Relationships With the Students, Community, and Land}

When the conversations turned to questions about what qualities mattered in the hiring process that would suggest a teacher might be successful over a long period of time in a First Nations community, each of the directors echoed similar comments: Positive relationships with students, families, and the community at-large, and the ability to connect to the land contributed to a teacher's success.

In response to a question about what each director believes makes a teacher successful in the long-term in her/his First Nation community, the following two examples illustrate the importance that relationships play in the minds of those responsible for hiring new teachers for First Nations schools:

They are teachers who are committed to their classrooms and they are committed to their students. They go above and beyond what they need to do. They won't let bad things happen to their kids. They know what matters to kids and what is important in their lives. That's what I am looking for when I hire. (Lhotse, personal communication, October 2011)

It is definitely someone who will venture out into the community, leave the confines of the teacherage and will go out onto the land. They need to be people who are interested in going out fishing and being with other people out on the land. They need to be people who are not afraid to socialize and become engaged 
with the people from the community. (Dhaulagiri, personal communication, September 2011)

In addition, one of the directors proposed that new teachers need to have a deep appreciation for the very close-knit familial relationships that exist and connect many people in a First Nations community.

We are a close-knit community and there are a lot of close relatives that live here. In one-way or another we've become related to one another, even if it's distantly so. Those relationships matter to everyone and new teachers need to understand that fact in their teaching and [in] how they connect with people. (Kangchenjunga, personal communication, November 2011)

These directors were looking to hire teachers who could make essential contributions to the quality of the educational experiences of their students.

In a report of 10 case studies of Aboriginal schooling success, Bell et al. (2004) concluded, "without a doubt, the establishment of strong and vibrant educational partnerships with parents is a particularly important asset in the process of education" (p. 298). These relationships, which are typically built on the "triadic dynamic of teachers, students and parents," writes Bell et al. (2004) in First Nations schools' contexts, "at their best extend to the whole school and extended families of students" (p. 298). In a more recent study that furthers Bell et al.'s conclusions, Fulford (2007) recognized that parent and community partnerships are one concrete way that allows schools and teachers to reach out and connect with the wider community to nurture student learning.

Dei, James, Karumanchery, James-Wilson, \& Zine (2003) suggested that First Nations schools, indeed all schools, should become places where "students can learn together with parents, adults and community workers" so that those external to the school not only "see themselves as significant partners and stakeholders but [also] as critical agents of educational change" (p.57). Thus, it should not be a surprise that these five directors wanted to hire teachers who would develop relationships with members of the local community and take part in the community’s way of life.

\section{Beliefs Commensurate With an Indigenous Worldview}

In hiring decisions, the five directors noted that they placed a high value on a candidate's espoused beliefs and what they assess as an alignment of those beliefs with what they believe are their communities' worldviews.

I think caring and being thoughtful, and not yelling and all that kind of stuff represent our culture...by being easygoing. I think we are gentle people. We are an easygoing people and teachers need to be like that. (Lhotse, personal communication, October 2011)

We have an eagle feather above the doorway to the school so that when people walk in they do it in a good way. We involve elders who come in to talk about the treaties. We also do drum groups and have people who do the jingle dress dance. All of this is about our culture and way of being and this is important for anyone who wants to teach here. (Cho Oyu, personal communication, October 2011) 
We have our creation stories and our spiritual beliefs; we believe in the circle, the directions, and the colours. Some follow the Seven Teachings but, to be honest, many people on the reserve have been colonized and don't believe in any of it. But, still I need a staff that has not been colonized and will resist the history of colonization. (Kangchenjunga, personal communication, November 2011)

Our traditional way of life is to live off the land... and the seasons play a big role in how we live and interact with the world. We expect our teachers to understand the importance of the land and the seasons. (Makalu, personal communication, January 2012)

We have a belief in using the eagle as a higher power. Our school is designed in the shape of an eagle and the main entrance faces east where the sun rises. We gather there as a staff because it says a lot about us. It's non-negotiable...before they come out here [to teach], especially for non-Natives, but actually for our people as well, they need to have developed a traditional, and I guess I mean an Aboriginal, perspective. Then they need to be able to come and use it in the classroom. They need to integrate that understanding of our way of life into their teaching. (Dhaulagiri, personal communication, September 2011)

For many Indigenous peoples, language, culture, knowing, and living are intricately related (Barnhardt \& Kawagley, 2005). The finding illustrates that these d directors seek to hire teaching candidates who possess a belief system that aligns with the ways First Nation peoples make sense of the world around them, as a dimension of their assessment of person-organization fit (Kristof-Brown, 1996). This is, however, no easy feat. Finding teachers who "are fully grounded in the teaching traditions of their nations," (p. 1080) is, as St. Denis (2010) contends, not as simple as declaring that is what is needed in First Nations schools and then searching for someone to hire who matches this ideal. Bell et al. (2004) maintain, "There is a serious shortage of certified Aboriginal teachers, especially with expertise in early childhood development, special education, reading, mathematics and sciences” (p. 319), and more recent research suggests that developing a deep enough talent pool of caring and competent Aboriginal teachers with the appropriate academic training that matches the needs of schools continues to be a struggle (Fulford, 2007).

\section{Teaching Students to Navigate Two Worlds Successfully}

It was critically important to these directors that they hire teachers who can help students to navigate successfully what Phelan, Davidson, and Yu (1998) have referred to as the borders of their community, with its culture and language and the requisite academic knowledge and skills required to be successful in school. Two of the participants made this most clear by stating:

I believe that we need teachers who are able to teach about our history and culture. But I also need teachers who can teach reading, or English, or mathematics or science because students need these to succeed. Some of our parents don't want their kids to learn Ojibwe. They will ask me: How does learning Ojibwe help my child succeed and go on to university? I try to explain that in order to be successful, to be you know whole, they need to know their 
history and culture and they need academics as well. I need teachers who can do both. (Lhotse, personal communication, October 2011)

Sometimes it is so sad because we will hire a non-Aboriginal teacher who will come in and have more knowledge about our culture and history than many of the teachers from our own community. For example, the teacher teaching treaties, land claims, and native history is a non-First Nations person. But, she is very passionate about her teaching, is extremely knowledgeable about the material and she believes in what she is doing. In the end, she is just good for kids. (Cho Oyu, personal communication, October 2011)

Two other directors spoke of the need to hire teachers to prepare students to consider life off the reserve. They offered that:

I want students to be taught to think outside the box, [who] have a view of what is out there in the urban cities and consider what might be out there for them. We spend a lot of time in our schools, starting at the early years, helping [students] to understand what is out there beyond this reserve. I think it's important for high school teachers to have kids thinking globally. To be thinking what is out there; in terms of career options. I think it's very important to hire teachers with this kind of mindset and then have them promote it in classrooms... When I hire I pay attention to what a person can offer as a teacher such as their major and minor area of study and their experience. I want to know they [new teachers] can contribute to this community in terms of learning. This is more important to me than whether they are First Nation, Chinese, or whatever. (Dhaulagiri, personal communication, September 2011)

In this community, we follow the Seven Teachings. So I need teachers who understand that fact. But, I also want kids to be prepared for life beyond the reserve. There is a big world out there and they need to be prepared for that. (Makalu, personal communication, January 2012)

Finally, one the directors identified the imperative and challenges related to supporting student achievement in mathematics and science. These are directly linked to a belief that there are insufficient numbers of new First Nations teachers academically qualified to teach mathematics and science. The following director believed that the shortage of wellprepared and capable mathematics and science teachers could be traced back to inadequacies in providing appropriate mathematics and science preparation from Kindergarten through Grade 12. As Kangchenjunga noted:

It is disheartening to think that we've lost a generation of children academically. It's made worse because one of those kids is my daughter. She is in university and doing well, although I know she struggles a lot in math because she didn't receive the strong foundation on reserve that she should have. When I think about partnering with a university to develop more Aboriginal teachers, I tell them I am willing to partner with them but only if math and science are going to be either majors or minors for these student teachers. No more Native Studies majors, please. It's true that we are going to struggle to get our kids to be math or science 
teachers, but it has to happen. It's what we need. (personal communication, November 2011)

The finding illustrates that the participants want to hire teachers who can support the development of students' understanding of their languages, histories, cultures, and traditional knowledges and who can teach the requisite knowledge and skills that are required to be successful in school. In short, it appears that the directors of education are looking for teachers who are committed to synthesizing two knowledge systems and supporting students to learn how to honour traditional worldviews as they navigate the present and plan for the future (Dei et al., 2003). This desire to find teachers who can support students in these ways is one tangible way for directors to help integrate Indigenous knowledge into schools and systems of schools that are structured on a Eurocentric worldview through their hiring decisions.

In many ways, this finding also echoes concerns raised by Bell et al. (2004), and Ingersoll and Perda (2009), who concluded that, although there is a shortage of competent mathematics and science teachers in general, this challenge is exacerbated in hard-to-staff school contexts. Whereas St. Denis (2010) has critiqued the hierarchical stratification of school subjects, such as the emphasis placed on mathematics, science, and English language arts that legitimizes the unequal status of some forms of school knowledge over traditional knowledge, the directors in this study expressed their desire to hire teachers who can help students gain the academic knowledge and learn the skills they need to participate fully in the local, national, and global economies of the $21^{\text {st }}$ century.

\section{Discussion}

While teachers must be ready to help students navigate successfully through an everchanging world and, necessarily, this includes students who attend on-reserve schools, the teacher workforce is simultaneously changing (Alberta Education, 2012). With teacher mobility rates at high levels across the spectrum of educational systems (Johnson, Berg, \& Donaldson., 2005; National Comprehensive Center for Teacher Quality, 2008; Peske, Liu, Johnson, Kauffman, \& Kardos, 2001), securing qualified, committed, and competent teachers for First Nation schools may only be possible through a greater focus on the kind and quality of teacher preparation that supports more robust understandings of the connection between First Nation peoples, the communities they live in, and the schools that operate on reserves (St. Denis, 2009; Wotherspoon, 2009).

Every organization, including schools, has a staff culture that has a history and underlying set of unwritten expectations that shape almost everything about how the adults in the school interact (Cranston, 2012a; Peterson, 2002). A school's culture influences the ways people think, feel, and act (Peterson, 2002), and research has illustrated that every school has a set of unspoken expectations about what can be discussed at staff meetings, what constitutes effective teaching techniques, how willing the staff is to change, and the importance of staff development (Deal \& Peterson, 1999).

The findings of this study suggest that these directors believe that they are able to shape a revised school culture through the hiring of teachers. They seek out teachers who are aligned with what they value in terms of teaching and learning, and this is a central focus of their hiring process decisions (Peterson \& Deal, 2002). This target is consistent 
with research that has suggested that educational leaders can and should help shape a school's culture (Peterson, 2002). Though, arguably, a limited approach that does not take into account the influence that the community at-large can have on a school's culture, one potent and crucial school improvement lever available to educational leaders is through their staffing decisions (Cranston, 2012a, 2012b; Peterson, 2002; Peterson \& Deal, 2002).

Undoubtedly, teachers hired to work in First Nation schools must be prepared to respond to the demands of a changing world. While popular media has championed the notion that cultural fit is more important than competence (Feld, 2012), the findings here suggest that these directors are seeking candidates who possess not only cultural competency (Domangue \& Carson, 2008) but also have the pedagogical content knowledge to teach the subjects they are assigned to teach (Shulman, 1986). Hiring teachers who have the necessary subject-area expertise in some academic disciplines has been a persistent problem for some First Nations schools (National Panel on First Nations Elementary and Secondary Education for Students on Reserve, 2012). These directors of education want to hire teachers to help First Nation youth to grow as members of their local First Nation community with the Indigenous knowledge and identity that allows them to be fully developed as First Nation peoples and to be prepared to thrive as they access the benefits of being citizens of Canada (Bell et al., 2004).

Echoing the importance that Day (2008) placed on the notion of teacher commitment and resiliency, the findings of this study suggest that First Nations hiring authorities want to attract and retain teachers who have an enduring belief that they can make a positive difference to the learning lives and achievements of their students through who they are, what they know and how they teach. This sentiment reflects a conclusion of Bell et al. (2004) who proposed that there is abundant research that identifies that teachers have a profound influence on the quality of their students' educational experience.

Clearly, First Nations students, like all students, require teachers who are effective at teaching them. Governments and universities must continue to open up spaces and support more members of First Nations communities who have the necessary subject-area expertise and are interested in becoming teachers (St. Denis, 2010). However, because of the lingering effects of colonization, undoubtedly even some who are First Nation may also need to be supported as they reclaim their understanding of First Nations history, culture, and ways of knowing as they become teachers.

Educational leaders in First Nations communities rely on faculties and colleges of education to select with prudence prospective teachers who have the capacity to be effective educators and then attempt to prepare them to assume the role of classroom teacher in a First Nation community (St. Denis, 2010). They also expect ministries and departments of education, and teacher certification boards to set teacher certification standards so that students, including students who attend First Nation schools, are taught by teachers who can effectively reach and teach them (Inglebret, Jones, \& Pavel, 2008).

In many ways, the findings of this study mirror the recommendations made by Barth (2006) who suggested that the individuals formally responsible for school 
leadership ought not to focus their attention on searching for teachers who seemingly demonstrate the ability to foster amorphous relationships that are difficult to describe and, thus, hard to use as a hiring criterion. These directors are concerned with hiring candidates who can foster consequential relationships (Blau \& Fingerman, 2009)—ones predicated by respectful adult-to-student relations, which can lead to improved student outcomes, however measured. In some regards, along an imaginary continuum of relationships, they are searching for teachers who will foster teacher and student relationships that occupy the middle ground of acting as more than complete strangers but less than intimates — our strongest connections — which are typically afforded to our very close familial relationships (Blau \& Fingerman, 2009).

Drawing on the recommendations of St. Denis (2010), prospective non-First Nations teachers must be prepared to understand and respect Indigenous ways of knowing, and to acknowledge the valuable contributions of First Nations' culture and history to Canada. With respect to First Nation peoples, culture must be understood to be more than a narrow list of espoused beliefs, observed practices, and adopted values. Culture needs to be more broadly understood as the worldviews, lifestyles, learned and shared beliefs and values, knowledges, symbols, and rites that guide behavior and create shared meanings within a group of people (Racher \& Annis, 2007). Drawing on a constructivist paradigm, the notion of Indigenous culture is better understood as being enacted relationally through lived and storied history, experience, gender, and social position (Browne \& Varcoe, 2006).

Although it is inappropriate to generalize the findings of this study to all First Nations schools or communities across Canada, it seems plausible that those charged with the responsibility with hiring teachers want nothing less than what was recommended in the 1996 Royal Commission on Aboriginal Peoples, which was to develop an education system staffed with competent adults who can nurture a generation of First Nations adolescents who understand, appreciate, and express themselves as Indigenous and have mastered the knowledge and skills that allow them to have access to the benefits of a contemporary global economy (Government of Canada, 1996).

\section{Concluding Thoughts}

For years there has been much rhetoric offered about the need for governments and its social public institutions to do a better job of meeting the legal and moral obligations that are owed to First Nations peoples and their communities. Faculties and colleges of education have a role to play and indeed a responsibility to better support the educational opportunities of students who attend band-controlled schools. Work is progressing to better prepare prospective teachers for increasingly diverse classroom contexts. However, those responsible for teacher preparation will need to consider how a significant portion of that preparation might need to be outside of traditional Westernized notions of the academic requirements of teacher certification. Being able to demonstrate a level mastery of academic subject matter, pedagogical knowledge, and competence in student teaching matters but may not be sufficient to reach and teach Indigenous youth.

Many ministries of education require university coursework in Aboriginal perspectives (for example see Manitoba Education, 2003), as part of the teacher 
certification requirements and, oftentimes, the courses are not taught in situ from the very locations that are inextricably intertwined with the subject of learning. Western philosophical conceptions of what constitutes formal schooling may not be best suited to transmit Indigenous' beliefs and practices through campus-based formal courses. From time-to-time, the design and delivery of a course may conflict with the very worldview of the Indigenous people it attempts to teach about (Barnhardt \& Kawagley, 2005). It is worth noting that Dei et al. (2003) recommend that faculties of education need to validate "the legitimacy of Indigenous knowledges as pedagogic, instructional and communicative tools in the process of delivering education” (p. 54). Such a commitment by teachereducators is significant because "synthesizing different knowledges means shifting to a restructured and reconstituted physical space, where issues of content and physical representation are dealt with to recognize the multiplicity of human ideas" (Dei et al., 2003, p. 54). Validating Indigenous knowledges within teacher education programs will require a paradigmatic shift by those responsible for teacher education. To this end, research is needed to explore how best to use different learning environments and pedagogical approaches to make the best use of Indigenous worldviews and associated knowledge systems to support student learning (Barnhardt \& Kawagley, 2005; Dei et al., 2003).

Though more empirical research is needed, the available research to-date supports the idea that high quality initial teacher preparation is an important precondition that supports student achievement (Goldhaber, 2007). Simply stated, well-prepared teachers outperform those who are not prepared (Goldhaber). Understanding Aboriginal students, their lives and communities, is no small feat given that Indigenous and Eurocentric societies’ worldviews differ greatly (Blaut, 1993). Much more work needs to be done within teacher preparation institutions to better inform prospective teachers and teachereducators of how Indigenous worldviews open up different understandings of education and schooling, and how a greater understanding and appreciation for Indigenous worldviews can help everyone relate better with each other and the world (Bell et al., 2004; Fulford, 2007; St. Denis, 2007, 2009).

Teacher attrition rates in First Nations communities far exceed those in other jurisdictions (Auditor General of Canada, 2004; St. Denis, 2010). However, as noted more than 20 years ago by Kirkness (1992) and re-emphasized recently by the National Panel on First Nation Elementary and Secondary Education for Students on Reserve (2012), the continued inadequate federal funding of First Nations schools has created tremendous pressure on finite financial resources and has left some First Nations educational authorities without the necessary dedicated funding to develop systematic approaches to recruit, professionally develop, and retain teachers. This is particularly vexing as research has demonstrated that teachers improve greatly between the first and third years of experience and effective human resources processes, ones that include coherent teacher orientation and induction processes and programs, will increase teacher retention rates (Wong, 2004).

Bell et al. (2004) poignantly identifies that attracting, professionally developing, and retaining qualified teachers for First Nations schools cost money (p. 319). What might help stave off the high levels of teacher turnover in First Nations schools are longterm federally funded teacher induction programs, designed and delivered by educational 
and community leaders in First Nation communities that align with Indigenous ways of knowing and being, and allow new teachers to better understand the challenges and opportunities that come with beginning a teaching career in a First Nations school and community.

Moreover, according to Leithwood, Louis, Anderson, and Wahlstrom (2004), the support, or lack thereof, that families provide to nurture a child's educational success has a profound impact on that child's level of in-school achievement. It is worth reminding ourselves that families of all backgrounds have aspirations for their children and they want to help support their children's achievement irrespective of familial income level, parental educational achievement levels, or cultural backgrounds (Cooper, Riehl, \& Hasan, 2010). Evidence suggests that educational leaders who are committed to developing the structures that allow students to succeed need to understand how schools, the teachers who work within them and the homes from which students come, are interconnected. Developing and then hiring teachers who are willing to engage a community response designed to sustain students' in- and out-of-school success should be a priority (Dei et al., 2003; Fulford, 2007; Leithwood et al., 2004).

As is the case in many provincially funded school jurisdictions (Cranston, 2012b), many of those who are charged with the very important job of staffing schools lack formal preparation and training in human resource management theories and best practices. The individuals responsible for hiring teachers need opportunities and continuous support so that they can work collaboratively to establish culturally relevant approaches that would lead to the development of effective recruitment and retention strategies designed to increase the likelihood of placing the best prospective teachers in First Nations schools.

Past research (Cranston, 2012a; 2012b; Peterson, 2002; Peterson \& Deal, 2002) has demonstrated that of those variables potentially open to policy influence, the decision of who is allowed to teach is arguably the most important in-school factor in student learning. Evidence demonstrates repeatedly that many of the structures embedded in formal education continue to fail First Nations students and their communities. However, research also illustrates that effective teachers can make a significant positive difference in the lives of students (Bell et al., 2004; St. Denis, 2010). Clearly, what is needed is better alignment of teachers with the criteria identified by these directors in this study, and also culturally appropriate and relevant hiring practices and policies designed to enable First Nation educational authorities to recruit and retain the very best of them to teach in First Nations' schools. 


\section{References}

Alberta Education. (2012). A transformation in progress Alberta's ECS-12 education workforce 2011/2012. Retrieved from http://www.education.alberta.ca/admin/workforce.aspx

Anderson, D., Horton, L., \& Orwick, S. (2004). Aboriginal teacher education: Issues for First Nations communities. Toronto, ON: Chiefs of Ontario.

Auditor General of Canada. (2004). Report of the Auditor General. Ottawa, ON: House of Commons. Retrieved from http://www.oagbvg.gc.ca/internet/English/parl_oag_200411_e_1124.html

Bailey, D. M., \& Jackson, J. M. (2003). Qualitative data analysis; challenges and dilemmas related to theory and method. American Journal of Occupational Therapy, 57(1), 57-65.

Barth, R. S. (2006). Improving relationships within the schoolhouse. Educational Leadership, 63(6), 8-13.

Barnhardt, R., \& Kawagley, A. O. (2005). Indigenous knowledge systems and Alaska Native ways of knowing. Anthropology and Education Quarterly, 36(1), 8-23. Retrieved from http://ankn.uaf.edu/Curriculum/Articles/BarnhardtKawagley/Indigenous_Knowle dge.html

Bell, D., with Anderson, K., Fortin, T., Ottmann, J., Rose, S., Simard, L., Spencer, K. \& Raham, H. (Ed.). (2004). Sharing our success: Ten case studies in Aboriginal schooling. Kelowna, BC: Society for the Advancement of Excellence in Education. Retrieved from http://www.saee.ca

Blau, M., \& Fingerman, W. (2009). Consequential strangers: The power of people who don't seem to matter...but really do. New York, NY: W. W. Norton.

Blaut, J. M. (1993). The colonizer's model of the world: Geographical diffusionism and Eurocentric history. New York, NY: Guilford Press.

Browne, A. J., \& Varcoe, C. (2006). Critical cultural perspectives and health care involving Aboriginal peoples. Contemporary Nurse, 22(2), 155-167.

Canadian Council on Learning. (2008). Students on the move: Ways to address the impact of mobility among Aboriginal students. Retrieved from http://www.cclcca.ca/ccl/Reports/LessonsInLearning/LinL20080515AboriginalMobility.html

Cooper, C., Riehl, C., \& Hasan, A. (2010). Leading and learning with diverse families in schools: Critical epistemology amid communities of practice. Journal of School Leadership, 20(6), 760-790.

Cranston, J. (2012a). Evaluating prospects: The criteria used to hire new teachers. Alberta Journal of Educational Research, 58(3), 1-18. 
Cranston, J. (2012b). Fitting in and getting hired. Canadian Journal of Educational Administration and Policy, 135(August). Retrieved from http://www.umanitoba.ca/publications/cjeap.

Creswell, J. W. (2012). Educational research: Planning, conducting, and evaluating quantitative and qualitative research ( $4^{\text {th }}$ ed.). Toronto, ON: Pearson.

Davidson-Hunt, I. J., \& O'Flaherty, R. M. (2007). Researchers, Indigenous peoples and place-based learning communities. Society and Natural Resources, 20(4). 291305.

Day, C. (2008). Committed for life? Variations in teachers' work, lives and effectiveness. Journal of Educational Change, 9(3), 243-260.

Deal, T. E., \& Petersen, K. D. (1999). Shaping school culture: The heart of leadership. San Francisco, CA: Jossey-Bass.

Dei, G. J. S., James, I. M., Karumanchery, L. L., James-Wilson, S., \& Zine, J. (2003). Removing the margins: The challenges and possibilities of inclusive schooling. Toronto, ON: Canadian Scholar Press.

Domangue, E., \& Carson, R. L. (2008). Preparing culturally competent teachers: Servicelearning and physical education teacher education. Journal of Teaching in Physical Education, 27(3), 347-367.

Elbaz-Luwisch, F. (2007). Studying teachers' lives and experience: Narrative inquiry into K-12 teaching. In D. J. Clandinin (Ed.), Handbook of narrative inquiry mapping a methodology (pp. 357-382). Thousand Oaks, CA: SAGE.

Feld, B. (2012). Cultural fit trumps competence. Retrieved from http://blogs.wsj.com/accelerators/2012/12/12/why-cultural-fit-trumpscompetence/

Fulford, G. (2007). Sharing our success: More case studies in Aboriginal schooling. Kelowna, BC: Society for the Advancement of Excellence in Education. Retrieved from http://www.saee.ca

Geisler, C. (2000) Estates of mind: Culture's many paths to land. Society \& Natural Resources, 13(1), 51-60.

Goldhaber, D. (2007). Everybody's doing it, but what does teacher testing tells us about teacher effectiveness? Center on Reinventing Public Education Report No. 9. Retrieved from www.caldercenter.org/PDF/1001072_everyones_doing.PDF

Goodlad, J. I. (1984). A place called school: Prospects for the future. New York, NY: McGraw Hill.

Government of Canada. (1996). Report of the Royal Commission on Aboriginal Peoples Volume 1: Looking forward, looking back. Ottawa, ON: Minister of Supply and Services Canada. 
Government of Canada. (2011). Census profile. Retrieved from http://www12.statcan.gc.ca/census-recensement/2011/dp$\mathrm{pd} / \mathrm{prof} /$ index.cfm?Lang $=\mathrm{E}$

Hargreaves, A. (1997). Rethinking educational change: Going deeper and wider in the quest for success. In A. Hargreaves (Ed.), Rethinking educational change with heart and mind: 1997 ASCD Yearbook (pp. 1-26). Alexandria, VA: ASCD.

Hill, R. (1995). Introduction. In J. Barreiro (Ed), Native American expressive culture. (pp. 3-11). Ithaca, NY: Akwe Kon Press.

Ingersoll, R., \& Perda, D. (2009). The mathematics and science teacher shortage: Fact and myth. CPRE Research Report \#RR-62. Retrieved from www.cpre.org

Inglebret, E., Jones, C., \& Pavel, D. M. (2008). Integrating American Indian/Alaska Native culture into shared storybook intervention. Language, Speech, and Hearing Services in Schools, 39. 521-527.

Johnson, S. M., Berg, J. H., \& Donaldson, M. L. (2005). Who stays in teaching and why: A review of the literature on teacher retention. A report sponsored by NRTA's Educator Support Network. Retrieved from http://hub.mspnet.org/index.cfm/12908

Kavanagh, B. (2000). First Nations schools: Challenging and rewarding places to teach. Retrieved from http://www.fnesc.ca/wordpress/wpcontent/uploads/2011/05/FN_Schls_Challng_\&_Rewarding_Cpyrt.pdf

Kavanagh, B. (2006). Teaching in First Nations schools: An information handbook for teachers new to First Nations schools. West Vancouver, BC: First Nations Schools Association.

Kovach, M. (2009). Indigenous methodologies: Characteristics, conversations and contexts. Toronto, ON: University of Toronto Press.

Kirkness, V. J. (1992). First Nations and schools: Triumphs and struggles. Toronto, ON: Canadian Education Association.

Kristof-Brown, A. (1996). Person-organization fit: An integrative review of its conceptualization, measurement, and implications. Personnel Psychology, 49, 149.

Leithwood, K., Louis, K. S., Anderson, S., \& Wahlstrom, K. (2004). How leadership influences student learning. Toronto, ON: Center for Applied Research and Educational Improvement, Ontario Institute for Studies in Education.

Manitoba Education. (2003). Integrating Aboriginal perspectives into curricula: A resource for curriculum developers, teachers, and administrators. Winnipeg, MB: Manitoba Education. Retrieved from http://www.edu.gov.mb.ca/k12/docs/policy/abpersp/ 
National Comprehensive Center for Teaching Quality. (2008). Lessons learned: New teachers talk about their jobs, challenges and long range plans, Issue 3: Teaching in changing times. Retrieved from www.publicagenda.org

National Panel on First Nation Elementary and Secondary Education for Students on Reserve. (2012). Nurturing the Learning Spirit of First Nation Students: The Report of the National Panel on First Nation Elementary and Secondary Education for Students on Reserve. Retrieved from www.firstnationeducation.ca/wp-content/themes/.../Report_02_2012.pdf

Parliament of Canada. (2011). Reforming First Nations education: From crisis to hope. Report of the Standing Senate Committee on Aboriginal Peoples. Retrieved from

Patterson, J. L., Purkey, S. C., \& Parker, J. V. (1986). Productive school systems for a nonrational world. Alexandria, VA: ASCD.

Peske, H. G., Liu, E., Johnson, S. M., Kauffman, D., \& Kardos. S. M. (2001). The next generation of teachers: Changing conceptions of a career in teaching. Phi Delta Kappan, 83(4), 304-311.

Peterson, K. D. (2002). Positive or negative. Journal of Staff Development, 23(3), 10-15.

Peterson, K. D. \& Deal, T. E. (2002). Shaping school culture field book. San Francisco, CA: Jossey-Bass.

Phelan, P., Davidson, A. L., \& Yu, H. C. (1998). Adolescents’ worlds: Negotiating family, peers, and school. New York, NY: Teachers College Press.

Polkinghorne, D. E. (1995). Narrative configuration in qualitative analysis. Qualitative Studies in Education, 8(1), 5-22.

Racher, F. E., \& Annis, R. C. (2007). Respecting culture and honoring diversity in community practice. Research and Theory for Nursing Practice, 21(4), 255-270.

Schwandt, T. (2000). Three epistemological stances for qualitative inquiry: Interpretation, hermeneutics and social constructivism. In N. Denzin \& Y. Lincoln (Eds.), Handbook of qualitative research (pp. 189-214). Thousand Oaks, CA: SAGE.

Sergiovanni, T. J. (1995). The principalship: A reflective practice perspective. Needham Heights, MA: Allyn and Bacon.

Shapes, L. (2011). Oral history. In N. Denzin \& Y. Lincoln (Eds.), The SAGE handbook of qualitative research ( $4^{\text {th }}$ ed.) (pp. 451-466). Thousand Oaks, CA: SAGE.

Shulman, L. (1986). Those who understand: Knowledge growth in teaching. Educational Researcher, 15 (2), 4-14.

St. Denis, V. (2007). Aboriginal education and anti-racist education: Building alliances across cultural and racial identity. Canadian Journal of Education, 30(4), 10681092. 
St. Denis, V. (2009). Rethinking culture theory in Aboriginal education. In C. LevineRusky (Ed.), Canadian perspectives on the sociology of education, (pp.163-182). Don Mills, ON: Oxford University Press.

St. Denis, V. (2010). A study of Aboriginal teachers professional knowledge and experience in Canadian schools. Ottawa, ON: Canadian Teachers Federation.

St. Denis, V., Battiste, M., \& Bouvier, R. (1999). Okiskinahamakewak - Aboriginal teachers in Saskatchewan's publicly funded schools: Responding to the flux (Revised 1999). Regina, SK: Saskatchewan Education. Retrieved from http://www.usask.ca/education/people/battistem/okiskinahamakewak.pdf

Stoll, L. (2002). School culture set: Research Information for Teachers, 3, 9-14. Retrieved from www.eductaionalleaders.gvt.nz/Culture/understadning-schoolcultures.

Tom, V. R. (1971). The role of personality and organizational images in the recruiting process. Organizational Behavior and Human Performance, 6, 573-592.

Wagner, C. R. (2006). The school leader's tool for assessing school culture. Principal Leadership, 7(4), 41-44.

Webster, L., \& Mertova, P. (2007). Using narrative inquiry as a research method: An introduction to using critical event narrative analysis in research on learning and teaching. New York, NY: Routledge.

Wilson, S. (2008). Research is ceremony: Indigenous research methods. Winnipeg, MB: Fernwood.

Wong, H., K. (2004). Induction programs that keep new teachers teaching and improving. NASSP Bulletin, 88(638), 41-58.

Wotherspoon, T. (2009). The sociology of education in Canada ( $3^{\text {rd }}$ ed.). New York, NY: Oxford University Press. 